\title{
Comparison of Corporate Governance Patterns of Multinational Corporations' Investment Enterprises in China
}

\author{
Huiping Tian \\ School of Economics and Management \\ Yanbian University \\ Yanbian, China
}

\author{
Ying Shen \\ School of Economics and Management \\ Yanbian University \\ Yanbian, China
}

\author{
Lan Liu* \\ School of Economics and Management \\ Chongnam National University \\ Daejeon, Korea \\ *Corresponding Author
}

\begin{abstract}
In the increasingly open market environment and the gradually developed market supervision system, the implementation of corporate governance pattern has become one of the important indicators to measure a company's development level. Multinational companies are the emerging enterprises with large investment I China, forming the key component of China's socialist market economy. The multinational corporations' corporate governance pattern is more and more compelling. Multinational corporations have a variety of governance patterns due to their own limitations and external environment. These modes have become the advantages of multinational corporations in China, which are conducive to the development of China's socialist market economy. This paper will make comments and suggestions about how to improve multinational corporations' governance pattern and to promote the better development of multinational corporations through analysis of the problems exist in corporate governance pattern and the causes.
\end{abstract}

Keywords-international corporation;

corporation governance patterns; investment

\section{INTRODUCTION}

Multinational corporate governance: With the economic globalization, many multinational companies have settled in China one after another. The essence of multinational corporate governance is the corporate governance structure of parent-subsidiary corporation. Most of the agency problems of today's enterprises are caused by the separation of enterprises' ownership and management rights. There may be a variety of agency problems existing between large shareholders and small and medium-sized shareholders. In order to realize the value of all personnel better, all employees, including large and small and medium-sized shareholders, need to introduce the corresponding structure and mechanism of corporate target management, namely corporate governance. Therefore, corporate governance is to solve the interrelationship among shareholders, board of directors and the managers. Corporate governance mainly includes two aspects: the governance structure and governance mechanism.

\section{OVERVIEW OF BASIC PROBLEMS OF MULTINATIONAL CORPORATE GOVERNANCE}

\section{A. Decentralized Shareholding}

The American investment corporations in China technically prefer invest wholly-owned enterprises, and conduct joint venture in the industries with low requirements of patented technical content. In view of the fact that the controlling stake is directly linked to the enterprises' profits, American corporations often require a majority of the controlling interests in the negotiations.

In terms of the governance structure, generally, the structure of American investment corporations is relatively simple, and only has the board of directors. The role of the American sole proprietorship's board is small. The directors are mainly representatives from the headquarters or genera manager of the company. However, in the joint venture, the board of directors often plays a greater role, mainly because it is related to joint venture and other issues, and the number of directors of both parties shall be determined according to shareholding structure proportion. The general manager is decided directly by the board, but from the headquarters. In the field of governance mechanism, the control force mainly comes from the parent company's control of the manager. Moreover, the company offers a variety of generous remuneration to relevant staff, such as higher wages and various prizes. 


\section{B. Centralized Shareholding}

In the area of equity structure, Japanese investment enterprises in China mainly exist in the form of joint ventures, regardless of the industry is important or not, moreover, the proportion of such joint ventures is quite high.

In the field of governance structure, the board of directors of Japanese enterprises is often composed of the operating personnel and the senior management, mostly 3-6 people; and Japan's parent company directly appoints the general manager; in addition, the Japanese side pays attention to the role of party branch and labor union.

In the field of governance mechanism, the general manager of Japanese investment enterprises in China has more spiritual requirements, yet their material requirements are generally low; The economic interests of general manager of the parent company in China are often consistent with the requirements of the Japanese headquarters, and if the general manager of the subsidiary does something bad and faithless to the general manager of parent company, the consequences are extremely bad. So, in order to prevent the emergence of such situation, few Japanese investment companies in China are directly under the management and control of the parent company.

\section{Joint Venture}

In China, the Korean enterprises are mainly joint ventures, cooperating with China in the form of economic joint venture cooperation. Samsung Electronics Company has made investment into a lot of enterprises, and most are in the form of economic joint venture cooperation. This type of equity is based on the following two aspects: First, better understanding of the specific investment in Tianjin, and second, a lot of economic risks are avoided through joint venture, and conduct large scale economic investment when the company gets better, thereby controlling the company.

In terms of governance structure, the Korean companies have a board of directors, and the number of directors in the board is determined by the equity capacity controlled by both parties. This is generally the case; the staff from Korean company holds the position of general manager, while Chinese staff mainly holds the positions of chairman and deputy general manager.

\section{COMPARATIVE ANALYSIS OF CORPORATE GOVERNANCE PATTERNS OF INVESTMENT ENTERPRISES IN} CHINA

\section{A. Equity Structure and Its Characteristics}

1) Corporate governance patterns of typical countries: According to the level of economic development, the legal system of various countries are not the same, the investing and funding means are not the same, so the corporate governance between countries is quite different. There is Anglo-Saxon mode based on the stock market, GermanyJapan mode with bank as the center, as well as the modes characterized by group formed by stakeholders, such as Japan's kei retsu (Sogo-Shosha), Chaebol in Korea and
European Control Company. There is also the mode featured by family holding structure, including Canada, Italy and some Southeast Asian countries. As early as 1998, four economists LaPortaR., Lopezde-SianesF., Shl ei ferA., Vi shnyR. W (Collectively known as LLSV) tried to explain various corporate governance patterns by classifying the data from dozens of countries and regions into four kinds of economic systems, the first is a universal Anglo-Saxon mode, as well as the French mode, the German mode and Scandinavian mode. It can be seen from the governance of various enterprises after 1990s, "the classification proposed by LLSV has gradually become the mainstream classification method in the academic cycle.

2) American corporation governance pattern: American company is the shareholder mastering company power, and the corporation affairs are determined by general meeting of shareholders, board of directors and managers together. Shareholders' meeting consists of all shareholders of the company, which is the power organ of the company, enjoying the supreme power. Moreover, it also determines the law and regulations regarding company's important affairs. The board of directors is elected by the shareholders' meeting, and it is the decision-making organ of the company. The board of directors has the right of enforcement and supervision. American company does not set up a board of supervisors, but conducts supervision and executes the supervision right against executive director and manager via Audit Supervision Committee, Nomination Committee and Remuneration Committee. In addition, it is responsible the company's daily management. America corporate governance pattern is known as a single-tier corporate governance pattern.

3) German corporate governance pattern: The key point of German corporate governance is that the board of supervisors has high status with great power. In Germany, the board of supervisors is composed of representatives elected from the shareholders' meeting and the employees, so they are high-powered. The board of supervisors manages the board of directors and is responsible for selecting the members, manages the company's daily works and supervises the company. The board of supervisors conducts the relevant supervision and management of the members of the board of directors, exercises the decision-making power of the shareholders' general meeting, and supervises and manages the board work and the daily economic activities. The board of directors of German companies, like the managerial structure in the American corporate governance pattern, is primarily engaged in day-to-day operations and economic management. Germany's double-tier corporate governance structure matches the fundamental power restriction thought of its centralized equity.

4) Japanese corporate governance pattern: The Japanese corporate governance pattern is that the board of directors and board of supervisors are directly elected through the shareholders' meeting. The shareholders' meeting is the highest authority of the company, determining and managing article of association, electing the company's board of directors and board of supervisors, and determining whether or not to approve company's proposal about capital 
reduction, merger, dissolution, profit distribution as well as remuneration of directors and supervisors. But the shareholders' meeting can set up examiner directly neglecting the two organs, and invite the accounting firm to conduct annual audit of the company and issue an authoritative audit report, enabling the shareholders' meeting to restrict the power of board of supervisors by using external power to supervise functions of the board of directors and senior management, and to supervise whether the power is misused. The board of directors governs the company's business decisions and the implementation of daily economic activities. The board of supervisors manages the company's executive staff and the organ it supervises, being responsible for investigating the illegal acts and serious misconduct of the company's executives and shall be responsible for financial audit of the company. Moreover, managers have certain independence, being not subject to the will of the shareholders. The managers have broad decisionmaking power, including both the company's daily business activities and the company's long-term strategic direction. So as for the Japanese corporate governance, the management often takes the dominant position.

\section{B. Setting of Board of Directors and Rights Allocation}

1) Shareholding ratio: The key to corporate governance is the shareholders shareholding ration, which is divided into two opposing situations: concentration and dispersion. The decentralization of shareholders' shareholding ratio is an important feature of the corporate governance pattern in America. And the dispersion characteristics are manifested as that the shareholding ratio of individual is increasing, and most of them hold shares, resulting in equity dispersion and separation of company's ownership and management. And the shares have great instability and the company controlled by the operator. In contrast, Germany and Japan's capital market is underdeveloped, the company's assets rely on banks, and the banks are creditors and shareholders. The major shareholders has high shareholding ratio with strong stability.

2) Corporate governance structure: The American corporate governance pattern is that the important issue of company is determined by the single major shareholder, and the board of directors of the company has the executive power and supervision power. The board of directors is unique. In addition, the American company emphasizes the power board of directors and the implementation and uses the independent directors to contain management, so that the board is independent without the interference from management. Moreover, the management must admit their mistakes when facing them, to prevent management remove their responsibility. The members of board of supervisors of German companies are the representatives elected from members of the shareholders' meeting and employees, so they have high position and great power. Board of supervisors manages board of directors and is responsible for selecting its members, manages the daily affairs of the company and supervises the company. The board of supervisors is responsible for managing the board of directors.
3) Incentive mechanism: In order to encourage employees to increase wealth for the company, the American corporations combine the employees' interests with through employee participation in dividend distribution. In this way, the staff's lazy mood can be prevented, and the interests of managerial personnel and shareholders can be linked together. German and Japanese corporations rely on clearly planned career, unemployment prevention, awards and other guaranteed and identified incentive mechanism to carry out lasting incentive for workers.

4) Governance purposes: The purpose of corporate governance in America is to maximize the interests of shareholders; the German company's governance has the purpose of maximizing social benefits. American companies attach importance to short-term benefits, considering the maximization of shareholder wealth is the utmost purpose of the company; while German and Japanese corporations attach importance to long-term interests, take the initiative to assume social responsibility and obligations, thinking that the corporation operation shall not only satisfy the owner, but also consider other stakeholders.

\section{REFERENTIAL SIGNIFICANCE OF CORPORATE GOVERNANCE PATTERN OF MULTINATIONAL CORPORATIONS TO CHINA'S ENTERPRISES FOR FOREIGN INVESTMENT}

\section{A. Defects of Various Corporate Governance Patterns}

$\mathrm{Eu} \cdot$ Levi proposed the concept of economic globalization in 1985 , yet there was no clear statement to explain the concept. The International Monetary Fund (IMF) explains economic globalization in this way, namely economic globalization refers to the increase in the scale and form of transnational trade in goods and services and capital flow, and the broad and rapid spread of technology enhance the interdependence of the world economy. The Organization for Economic Cooperation Development (OECD) stated in a report that economic globalization can be seen as a process in which economic, market, technology and communication forms are having more and more global characteristics, yet the national and local characteristics are reducing. In the context of economic globalization, the external control of British and American corporations, the internal control of German and Japanese companies integrated with each other harmoniously.

The economy of Japan, South Korea and other developed countries rose after World War II developed rapidly. The political environment of these countries is conducive to their economic development. Moreover, national characteristics are used in corporate governance patterns. However, after the Asian financial crisis in 1998, a series of problems in the governance patterns of corporations in Korea and Japan were revealed. After the crisis, corporations of South Korea and Japan profoundly reflected on their corporate governance patterns, and it was concluded that the loose system, weak regulation, loose corporate governance pattern led to the worldwide crisis. The Asian corporate governance pattern was not the only that did not withstood the baptism of financial crisis, the European companies also faced the test 
from financial crisis on their corporate governance pattern, resulting in international comparison. The crisis also attracted worldwide attention, because many of the world's funds were invested in the developing Asian countries. So the sluggish performance of these companies, the collapsed stock market will lead to damage to the economic income of developed countries worldwide. Therefore, facing economic globalization, even if the financial crisis only appear in Asia, the continuous movement of international capital connects the economy of developing countries and developed countries together. Similarly, corporations in Britain and America are not in peace. Since 2001, Enron incident and WorldCom event, as well as other vicious events reveal the problems of American corporate governance, making people have doubts about you, and further promote the American corporate governance reform. These issues suggest that corporate governance issues arise both in Asia and in the United States, demonstrating the universality of the corporate governance pattern crisis. Many international organizations are committed to solving these problems. Since the publication of the first corporate governance principle in the world, namely, "Financial Issues in Corporate Governance Structure", countries around the world and various interest groups have conducted survey on corporate governance pattern, and published the scheme with the aim of creating a health pattern of corporate governance and so on. In 1999, the World Bank and the World Economic Cooperation Organization jointly established the "Global Corporate Governance Forum", aiming to further standardize the corporate governance pattern in developing countries. Countries in the world refer to the corporate governance structure specified by the World Economic Cooperation Organization (OECD) and follow the normative corporate governance structure so as to further strengthen corporate governance, which has accelerated the homogenization of corporate governance throughout the world.

\section{B. Rationality of Existence of Various Governance Pattern}

It can be seen from the analysis that the external control pattern of British and American corporations as well as the internal control pattern of German and Japanese companies has undergone significant changes. However, it should be noted that such convergence is only a relative one. No matter the American or British corporations, or German and Japanese companies, they are not completely broken away from their original track and deep-rooted governance pattern. It is the path dependence pattern that makes the stability of German and Japanese companies comes first, for instance, up to now, although the German corporate governance pattern has undergone some changes like above mentioned, there is no fundamental change. The governance pattern of Germany has not been completely replaced by shareholderoriented theory, and the direction is still the theory of stakeholders and internal control theory. In terms of internal structure mechanism, the common decision mechanism and trade union system are still deeply influencing the legal environment and facts of the company in Germany. German companies' internal structure mechanism will not change significantly in the near future, because Germany has a unique economic background. As for the shareholding ratio, the major shareholders are still the banks, and most of the small shareholders are individuals, securities investment is only applied to a small number of companies. Therefore, as for large shareholders are the banks, the German companies' equity mode tends to be concentrated. It can be known from the number of listed companies that the German securities market is still lagged behind. In 2015, the number of German listed companies was far behind that of the America. In terms of the corporate governance structure, although German companies follow British and American corporate governance patterns in some aspects, such as the independent director structure, to strengthen external supervision of the board of supervisors, the German corporations mainly adopt the internal control system and double-layer system, so the internal control system will play a role. As a result, despite the current changes in the path of German financial system, the new governance model is not irrelevant to the previous pattern. There is a correlation in corporate governance pattern, therefore, Germany's current corporate governance system not only contains a new market-oriented system, but also contains the previous bank-oriented system.

\section{Referential Significance}

In the rapid development of economic globalization, the relevant laws and regulations shall be improved in accordance with China's practice and international development speed, to reduce the risk in investment under the condition of further improving the investment environment. Chinese enterprises should actively participate in the corporate governance of multinational companies in China, and earnestly pay attention to the rights they should enjoy.

The foreign parent company of multinational companies strengthen the control of the company using technology investment, and it should promote China to enter into the international division of labor and global production R\&D chain at a higher level, but not just a processing plant of the multinational company in foreign country. However, the use of advanced technology of subsidiaries and parent company enhances the trend of international advanced technology to turn to China. Second, encourage and guide multinational companies to expand to knowledge-based and serviceoriented areas such as training, distribution and R\&D from the processing, manufacturing and other fields.

As for China's domestic enterprises, it is also very important to optimize the agent's "incentive-constraint compatibility" mechanism: First, offer material incentives to the agents through various forms, such as reasonable allocation of residual claims, stock issuance and stock options, "in-service consumption" and high retirement salary; moreover, carry out spiritual incentives via job promotion, job challenges and sense of accomplishment as well as social responsibility or national pride and other forms; Second, restrain the agents through the combination of external supervision and internal control.

China is in the transition period, the core of corporate governance pattern is the establishment of a modern enterprise system. The major issue to solve the problem of 
corporate governance in China is to establish an enterprise internal governance system with reasonable structure and perfect functions. In China, to participate in the fierce competition in the market, and facing the challenges of globalization, we shall make efforts to learn from multinational corporate governance pattern, investigate current situation of corporate governance pattern of multinational companies in China systematically, and further promote the domestic enterprise governance pattern and standard operation, and actively respond to the wave of economic globalization competition.

\section{REFERENCES}

[1] Gao Yang. Comparison of Corporate Governance Patterns of American, Japanese and South Korean Multinational Corporations' Investment Companies in China [J]. THEORY HORIZON. 2009 (7)

[2] International Monetary Fund. World Economic Outlook. [N] . 2014 (7)

[3] Lv Yanfang. Economic Globalization and China 's Economic Development. [J]. Coastal Enterprises and Science \& Technology. 2009 (7)

[4] Li Jiming. Analysis of Corporate Governance Trends under Globalization: Pattern Convergence or Function Convergence. [J ]. Zhejiang Academic Journal. 2005 (6)

[5] Yang Jifei. Corporate Governance Pattern of Multinational Corporations' Foreign-funded Enterprises in China and Its Enlightenment. [J]. Modernization of Management. 2002 (4)

[6] Chen Meng. Economic Globalization and International Economic Law. [J]. Heilongjiang Chronicles. 2013 (5)

[7] Ruo Shan. Alienation of Corporate System. [M]. Peking University Press. 2003. p80.

[8] CA. Shlei ferand R. W . Vi shny, / A Survey of Corporate Govemance0, Joumal of Finance. [N] . 1997, 52, p. 737-783.

[9] Meng Xianjun. Research on China's Foreign Trade Policy under Economic Globalization. [J] .Market Modernization. 2014 (4)

[10] Zhang Mi. Research of Impact of Economic Globalization on International Accounting. [N] . Modern Marketing. 2011 (3)

[11] Wang Hongjun. Influence of Economic Globalization on the Basic Principles of International Economic Law. $[\mathrm{J}]$. Legal System and Society. 2011(5). 